\title{
LUÍS DUARTE FERRO
}

\section{A Sacred Landscape \\ An enquiry into the 'cubas' of southern Portugal}

\section{$\mathrm{T}$} he purpose of this article is to study cubas - small architectural structures known for their whitewash-painted domes - and specifically, those located in the kûra of Beja in Portugal. Although we can pinpoint the existence of many of these buildings in the Beja territorial area, many questions remain about them, such as: What was the purpose of the cubas? When were they built? What is their origin?

In order to try and answer these questions, I will be following two methods of analysis. First, I will focus on the correlation that exists between these buildings and the landscape in which they are located. This can shed some light on the rationale behind their construction and the purpose of this type of structure. Secondly, I will analyse the buildings themselves - with special attention being given to metric and structural analysis - in order to clarify the period in which they were constructed and the origin of their architectural typology.

By means of this project I also aim to raise awareness, both within the academic community and amongst political decision-makers of the existence of these buildings and their importance for an understanding of Iberian-Islamic culture. Perhaps this will eventually inspire political action that will lead to the development of policies to ensure the preservation of this important part of our architectural and cultural heritage.

\section{Introduction}

Anyone who has travelled widely in the Arabic countries and in the regions that were once under Islamic rule - such as southern Iberia, the Balearic Islands, Sicily and Malta - is probably familiar with the cubas, certain whitewashed buildings, which are usually abandoned and in ruins, concealed in dense vegetation, or buried in dunes, damaged by the winds and the sand.
The dome is the main feature that identifies this type of construction; the one component that gives singularity to the cubas. In Portuguese, the word 'cuba' is a semantic hybrid of the Arabic word qubbâ and the Latin word cupa, both meaning 'dome' (Gonçalves 1964: 13; Borges 1985: 200; Carreteiro 1997: 7; Martos 1994: 13; Rei 2000: 202; Corriente 1986: 604). The main architectural characteristic of the cubas is a combination of the two basic shapes which compose them: a sphere (the dome) on a cube. Since Plato's Timaeus the cube has been associated with the element of earth (Martos 1994: 13), while the hemispherical shape - both in Plato's work and in all Oriental cosmogonies - is compared to the celestial welkin or sky (ibid. 13). Thus, the Earth and the Sky, in this combination of the cube and the dome, are used to represent the cosmos.

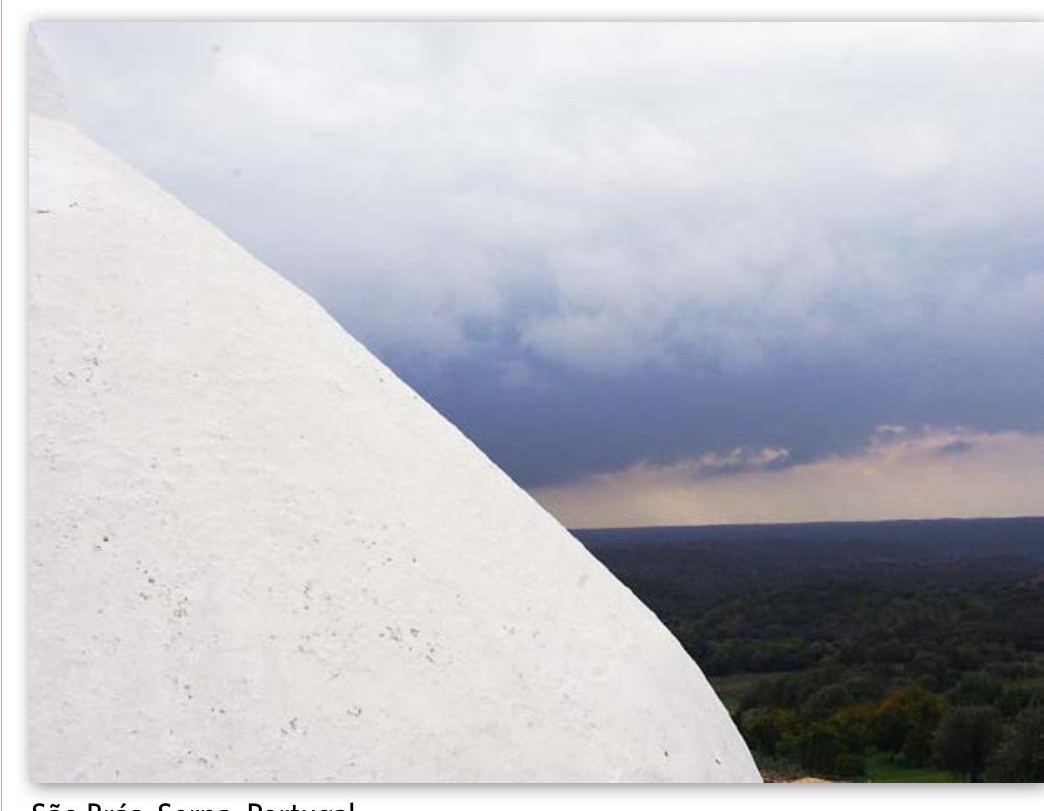

São Brás, Serpa, Portugal. 
The specific shapes of the base and the dome may vary from region to region, and the 'solutions to the transitions from the base to the dome can be more or less simple or complex' (Borges 1985: 199). A more thorough analysis may show that the cubas in 'Al-Masriq' (the east) are more monumental and vary more in form than those located in 'Al-Maghrib' (the west). Hence, we can identify the existence of an architectural subtype of cubas called the 'maghrebian', since many morphological similarities and resemblances in construction can be found between the cubas located in Morocco, Algeria, Tunisia, the Balearic Islands, Sicily, Malta and Andalusia.

For the purpose of this article - and in order to develop a more detailed analysis of the cubas - I will focus my attention on the study of the architectural elements of the cubas located in the kûra of Beja - the region's administrative division during Muslim rule - which occupies the territory which falls within the following geographical boundaries: the Sado and the Xarrama rivers, the Alvito Dam, the mountain range of Portel and the Ardila River to the north; the Caldeirão and Monchique mountain ranges to the south; the Aroche and Morena mountain ranges to the east (today part of Spanish territory); and the Mira River to the West (Macías 2005, Rei 2003).

Since an inventory of this type of building has never been made, the precise number of cubas that exist in the kûra of Beja is unknown. However, we can point to the existence of hundreds of cubas (Borges 1985: 200).

Although the original use of these buildings is still debatable, the majority of researchers argue that the cubas were sanctuaries that housed the remains of a Muslim saint, thus immortalizing and perpetuating his symbolic power (Gonçalves 1964: 12). However, the clear tie that exists between the cubas and the surrounding landscape has raised many doubts and also led to many hasty conclusions. For example, the historian Artur Goulart Borges sees the location of these structures - at the top of the highest mountains in southern Portugal - as a functional alliance between places of worship and military surveillance (Borges 1985: 199-200). According to Jorge Feio, some cubas are located on the official administrative borders of the Alvito County, which can be seen as evidence that

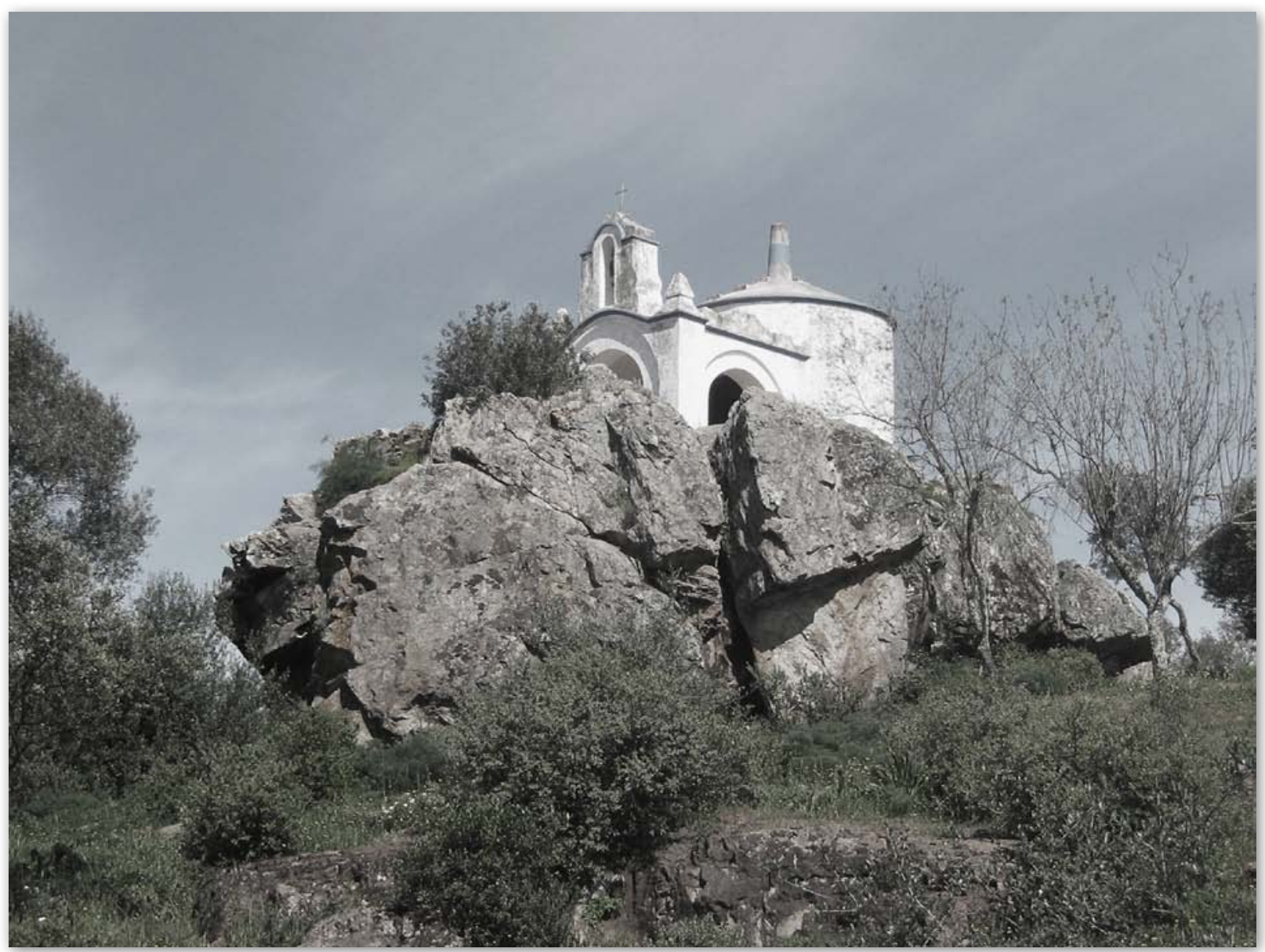

São Lourenço do Olival, Portel, Portugal. 
they were both religious in nature and had an administrative function in defining territory. José Pires Gonçalves adds the hypothesis that the cubas marked an Islamic necropolis (Gonçalves 1964: 14, 27).

However, the debate over the cubas goes far beyond their original purpose; the origin of these architectural structures and the precise dating of their construction is still a matter of dispute in the scientific community. Pires Gonçalves asks: were the cubas an architectural form imported from Northern Africa and built during the period of Muslim occupation in Portugal, between 711 and 1191? Or were they the 'expression of a very common type of funeral construction in the Iberian Peninsula during the period that preceded the Reconquista and then taken to the Maghreb by the Moorish architects that were expelled from the regions of Estremadura and Andalusia in 1502, and later in 1610?' (Gonçalves 1964: 13; Gabrieli 1965: 105).

Following these debates - and with the recognition that the cubas are underappreciated and too little attention has been given to their study - in this article, I hope to achieve two main goals:

1) To access the relevance of the landscape in the popular religious imagination. I will introduce historical data (such as the location of Roman fortifications and roads, burial sites, Muslim ribats and azóias, watchtowers and medieval convents) onto a map featuring the kûra of Beja, as well as geographic data (topography, rocky areas, vegetation, streams and rivers, ancient paths of transhumance, and pilgrimage routes), and the precise locations of the cubas I have chosen as my objects of study. By means of an analysis of this data I aim to shed some light on the issue of the original use of the cubas.

2) To complete the architectural and photographic survey and consequent inventory of the cubas of the kûra of Beja - thereby extending work started by Rui Miguel Carreteiro in the district of Évora. It is important to mention that Carreteiro's work did not sufficiently emphasise the existing articulation between the buildings and the surrounding landscape, nor did he give sufficient attention to the morphological, structural and metric features of the cubas. In this article I will take into account the importance of these features since they can offer useful evidence in establishing the period in which these buildings were constructed, which will be decisive in clarifying the migratory direction of this very specific architectural form.

\section{State of the art}

Most of the cubas that were chosen as objects of study in this article have never previously been part of any investigative work; it is not easy to find an architectural case study about the cubas and their connections to the surrounding landscape. A study that comes closest to being an introduction to this problematic area is Rui Miguel Carreteiro's work of 1997, entitled 'Cubas' no Alentejo (“'Cubas" in Alentejo'). Carreteiro made a series of architectural and photographic surveys that reveal a strong link between geography and the cubas located within the southern district of Évora (Carreteiro 1997).

Specifically in relation to the cubas located in Portuguese territory, we have already mentioned two of the most relevant papers that present historical investigations on the topic at hand: A cuba de Monsaraz ('The Cuba of Monsaraz') (1964) by José Pires Gonçalves, and As "kubbas" alentejanas. Monumentos de origem ou influência muçulmana no Distrito de Évora ('The "Kubbas" of Alentejo: originary monuments or Muslim influence in Évora', 1985) by Artur Goulart Borges. Both present the still-unanswered questions concerning the original use, date of construction and migratory direction of the cubas.

The study of Iberian political and cultural history during the period of Muslim rule was begun in Portugal by the Spanish architect Fernando Chueca Goitia when he presented his exhibition 'Peninsular Muslim Architecture and its Influence in Christian Architecture: A Photographic Exhibition Inaugurated in November 1962', at the Fundação Calouste Gulbenkian. Thirteen years after this pioneering exhibition, António Borges Coelho published his book entitled Portugal na Espanha Árabe ('Portugal in Arabic Spain', 1975), also a very important work to anyone who is interested in investigating Islamic Portugal. Also worth mentioning are the works of António Rei, such as A fronteira no Sudoeste peninsular (1234-1242). Novas visões da "reconquista" a partir do "al-Mughrib" de Ibn Saîd de Granada ('The Frontier of the Peninsula's Southeast (12341242): new views of the "Reconquista" from the "alMughrib” of Granada's Ibn Saîd'); José Luís de Matos' book Lisboa islâmica ('Islamic Lisbon', 1999); and the projects connected to the Mértola Archaeological Site under the supervision of Cláudio Torres and Santiago Macias.

At the international level Spain has undoubtedly done the most scientific research into this topic. I would like to highlight the pioneering works written by Torres Balbás: 'Rábitas Hispanomusulmanos' 


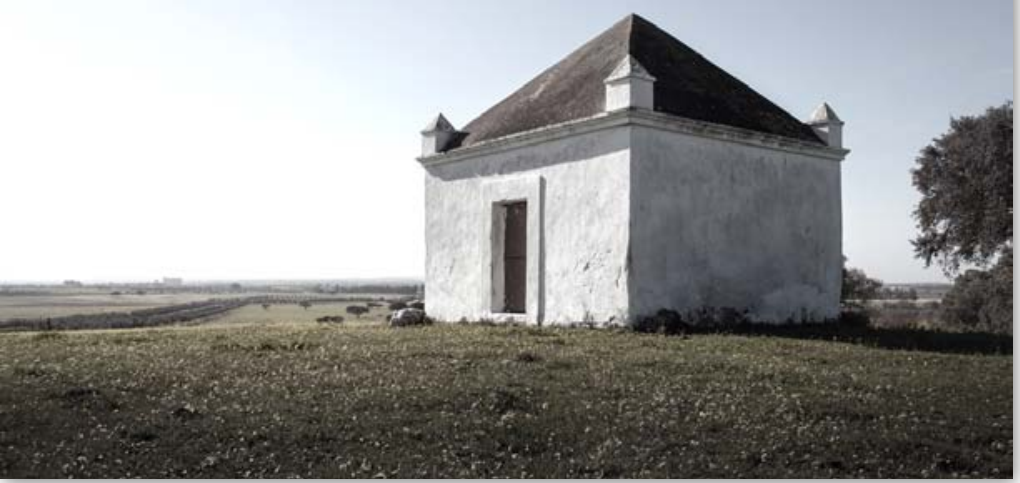

São Sixto, Cuba, Portugal.

(1948) and 'Cementerios Hispanomusulmanos' (1957), both papers published in the Al-Andalus Journal. Specifically concerning the cubas located in Northern Africa, I would like to mention the Hespéris Journal - especially the work of Henri Basset and Henri Terrasse, such as Chella, une nécropole mérinide ('Chella: a Merinide Necropolis', 1922) - and the Muqarnas Journal, particularly the papers 'Andalusian roots and Abbasid homage in the qubbat alBarudiyyin in Marrakech' (2008) by Yasser Tabbaa and 'The church of the cuba near Castiglione di Sicília and its cultural context' (1994) by Charles E. Nicklies.

These examples illustrate a lack of investigative studies of the cubas located in Beja. Most of the work that is available is focused on their historical aspects.

\section{Analysis of the cubas located in the kûra of Beja}

In order to access the relevance of the landscape for the popular religious imagination - the first aim of this project - I needed to have a macro-image of the landscape of the kûra of Beja. For that purpose I marked on a map of the region the precise location of the cubas as well as the relevant geographic and historical data. The overlap of information approximates this project to a study in the archaeology of space, since I am searching for traces of elements that may have been there and with which the cubas might share a strong link, 'as if all was united in one drawing; one ancient, great and unique project' (Grassi 1983: 38), 'where architecture is associated to the natural world through a system of relations in which the rules of proportion and dimension of the edifices seem to be an extension [of nature]' (Rabaça 2011: 156).

Such an ambitious task requires an historical understanding of the landscape of the kûra of Beja, specifically, how it was at the time when the cubas were constructed. This is an effort that orients us towards the past, to the period between the eleventh and fifteenth centuries. In order to fully grasp a territory and to unveil the mysteries of history we should not deem as unchangeable what has eventually changed (Duby 1992: 35). 'That mighty sculptor, time' (Yourcenar 1993) shapes and influences the landscape, darning, pulling, and replacing threadby-thread, line-by-line, the ensemble of its elements. Therefore ancient maps have great significance, since the information they convey not only renders possible such a return to the past, but also enlightens their reader as to the gradual evolution of the landscape.

Concerning this link between the landscape and the buildings, Artur Goulart Borges's study is an invaluable guide and an excellent starting point for my journey. In his study of the location of the cubas Goulart Borges proposes three typologies (Borges 1985: 200-1):

\begin{tabular}{|l|l}
\hline Type 1a & $\begin{array}{l}\text { Advantageous strategic situation on semi-level upland } \\
\text { terrain, which allows a broad panoramic field of vision } \\
\text { and isolation. }\end{array}$ \\
\hline Type 1b & $\begin{array}{l}\text { Advantageous strategic situation on semi-level upland } \\
\text { terrain (same as in type 1a) located in the peripheral } \\
\text { areas of human settlement. }\end{array}$ \\
\hline Type 1c & $\begin{array}{l}\text { Advantageous strategic situation (same as in type 1a) } \\
\text { located within human settlements. }\end{array}$ \\
\hline Type 2 & $\begin{array}{l}\text { Advantageous strategic isolated location near roads, } \\
\text { rivers or watchtowers. }\end{array}$ \\
\hline Type 3a & $\begin{array}{l}\text { Without any apparent advantageous strategic situation, } \\
\text { located in the peripheral areas of human settlements. }\end{array}$ \\
\hline Type 3b & $\begin{array}{l}\text { Without any apparent advantageous strategic situation, } \\
\text { located away from human settlements. }\end{array}$ \\
\hline
\end{tabular}

Table 1. Typologies according to Artur Goulart Borges (1985).

The emphasis Goulart Borges puts on Type 1 demonstrates the prominence given to the cubas located on places of high altitude, whereas the examples whose location is clearly connected to other features - such as roads, rivers, rocky areas, trees, or possible archaeological remains - were all classified as Type 2. The special importance conferred on high places can be pointed to as the cause for the doubts and contro- 


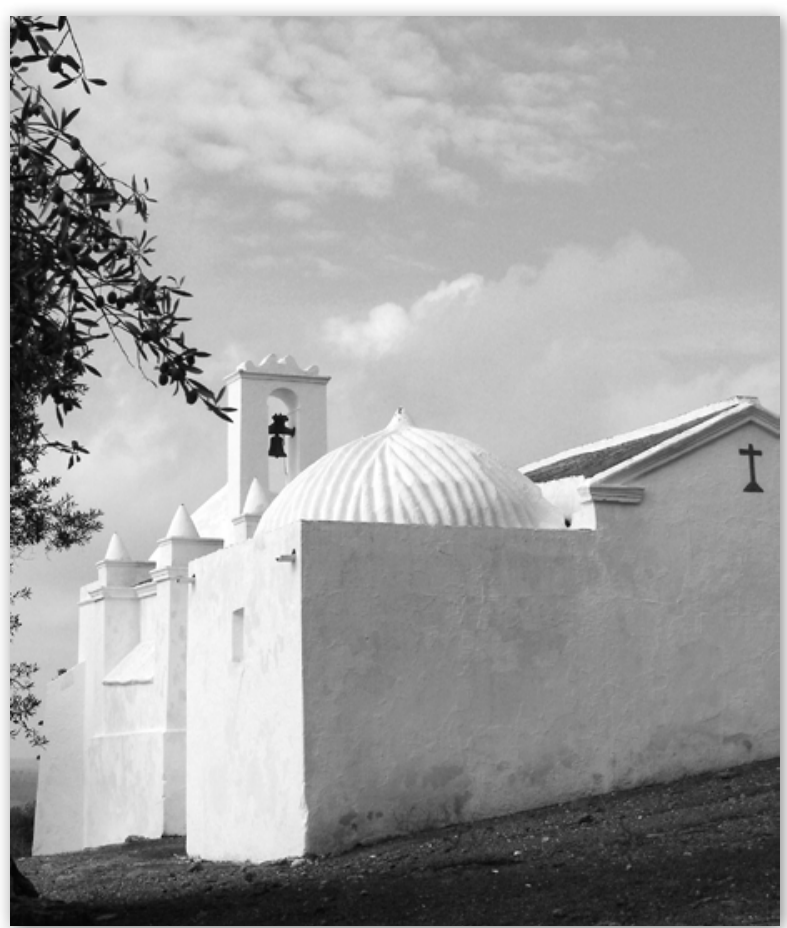

São Brás, Serpa, Portugal.

diseases. This hypothesis is supported by the similarity that the artifacts have with offerings made to Saint Lucy - patron of the blind and those with eye problems - and also by the fact that in Garvão, Saint Lucy was adopted as the region's patron Saint (and the village's community is still very devoted to her; Boiça 1998: 8).

\section{Cubes from Alentejo and domes from Arabia}

As I have already stated at the beginning of this article, the completion of a thorough inventory of the individual features of every cuba under analysis is essential to this project, especially the data concerning metric measurements and structural characteristics, since they can shed some light over the period of original construction. Later, and with the objective of better clarifying the migratory direction of this type of construction I will compare the data collected and analysed with the cubas of Northern Africa.

The thirty-two cubas analysed share the same type of a centralised ground plan comprising a square, circular or octagonal shape, whose sides or diameter vary in length between 5 and 5.50 metres and ends in a dome made of hemispherical or conical shaped fireclay (Gonçalves 1964: 13).

The principal shape of these buildings is given by an axis drawn from the front door entrance (to the northwest) to the altar (to the southeast) having a 24 degree angle in relation to the horizontal line of reference. On the pavement, a tombstone marks this axis.

The cubas analysed have the following characteristics:
Exterior

Interior
The walls of the base (cube) are heavy and robust. The weight of the dome is supported either by four arches embedded in the walls of the cube, or by masonry or partition walls.

The dome is made of fireclay and it is usually of circular shape.

The dome can have several exterior coatings, in some cases being lime-plastered, in other cases being coated with roof tiles that may or may not be whitewashed (as in the case of São Brás, Serpa).

The rainwater drainage is effected directly by the structure (Santa Luzia, Alvito) or it may occur by means of a platband which collects the water and conveys it through the gargoyles (São Vicente, Ferreira do Alentejo).

The fenestration is turned towards the south, has a vertical orientation, and its width varies between 5 to $10 \mathrm{~cm}$, height between 50 and $60 \mathrm{~cm}$. The interior and exterior corners have 45 degree angles and an embrasure with no glass.

The materials used in the stonework are marble (used in the doorway, doorposts and lintel) while the door itself is made of wooden planks arranged vertically.

Some of the examples have four decorative merlons on the upper corners of the cube near the basis of the dome.

Four simple or angular tubes make the transition between the dome and the cube.

The dome and the lateral walls are painted with frescos, usually with geometric shapes.

The altar is usually a small niche.

The floor is made of fireclay tile $(30 \times 30 \mathrm{~cm})$

Table 3. Structural characteristics of the cubas from the kûra of Beja. 


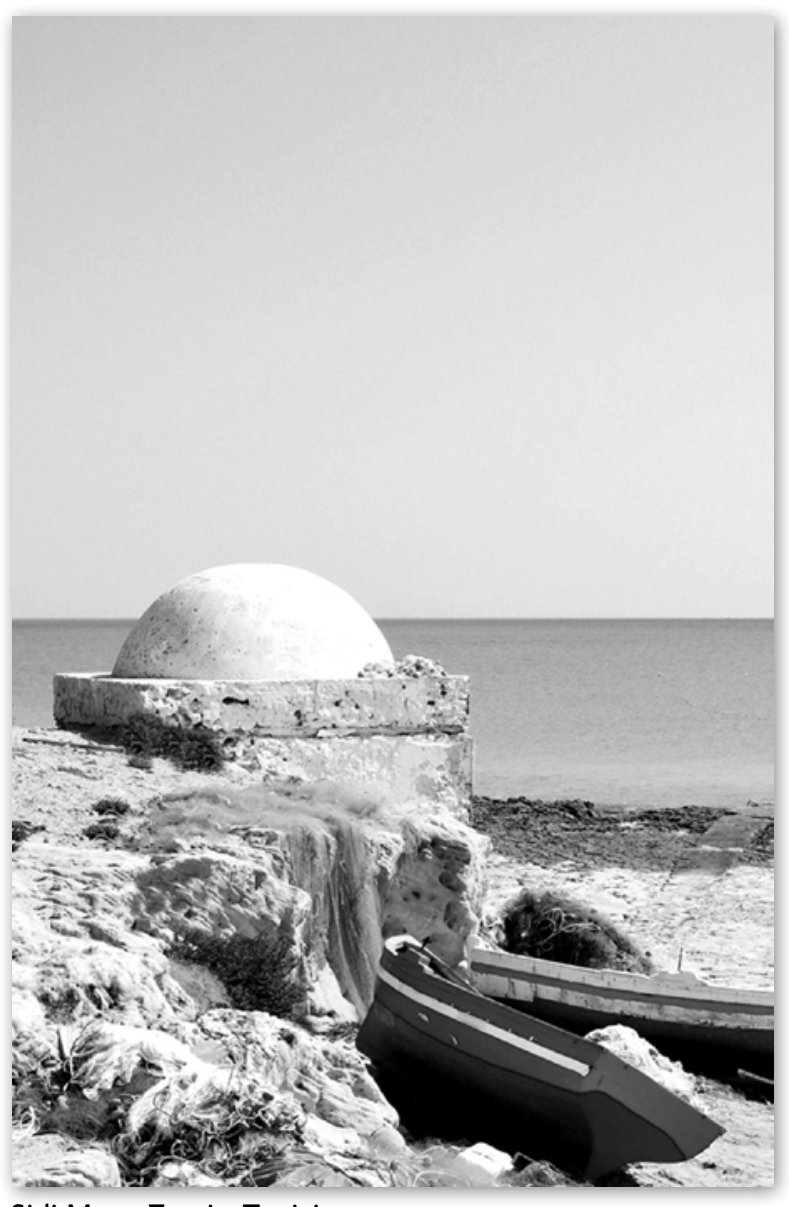

Sidi Meer, Zarzis, Tunisia.

In Alentejo, the buildings that present a squared plan and a dome are popularly referred to as 'cuba type constructions. This is an interesting expression that not only denotes the typological idea that is popularly connected to the Arabic cubas, but also reveals that this type of construction was common in the region, an architectural reference known by many, one that has endured until today.

Presently, some of the cubas in the kûra of Beja are not independent structures. This means that throughout the centuries, many changes were made to the original structure, and some cubas even became part of a new construction. This is actually very significantly different from the cubas of Northern Africa, since there most of the cubas present in their original shapes.

In Beja 'hermitages were built over the Qubbas' (Varela Gomes 2001: 20; Creswell 1958: 50) and thus, they were 'progressively integrated into broader architectural ensembles where the purpose of the space was converted, and so was its religious purpose' (Carreteiro 1997: 12). The most common transformation was to adapt the cuba and turn it into the presbytery and then to add the nave (where people attend mass) and the lobby's narthex. In some cases, the original $c u b a$ is found alongside the hermitage, connected to the presbytery, in the same place where we would find the sacristy in a church. The most curious cases are those where there was added to the original cuba a lobby's narthex. And in the even rarer cases when the $c u b a$ is located in a place where it is impossible to extend the building, a hermitage has been built as close as possible to the original construction.

This adaptation of the cubas, giving them new uses adapted to the needs of communities, was responsible for the inclusion into the architectural culture of Alentejo of this type of construction. The aforementioned popular expression 'cuba type constructions' is a reflection of this integration, which may also explain the existence of calvaries and other chapels with square-shaped or circular-shaped ground plans incorporating a dome and an masonry made with black shale - echoes of the ancient East, from old Mesopotamia to Christian Iberia that together create a culture full of mystery and beauty.

Having said that, how do we differentiate the original cubas from the 'cuba type constructions'? An analysis of the metric data can help clarify this issue.

The plans of Santa Luzia, São Vicente, São Sixto and São Sebastião have the exact measurements of the so-called Portuguese Andalusian cubit, which may lead to the conclusion that these examples were built by Muslims or Moorish architects between the eleventh and twelfth centuries AD.

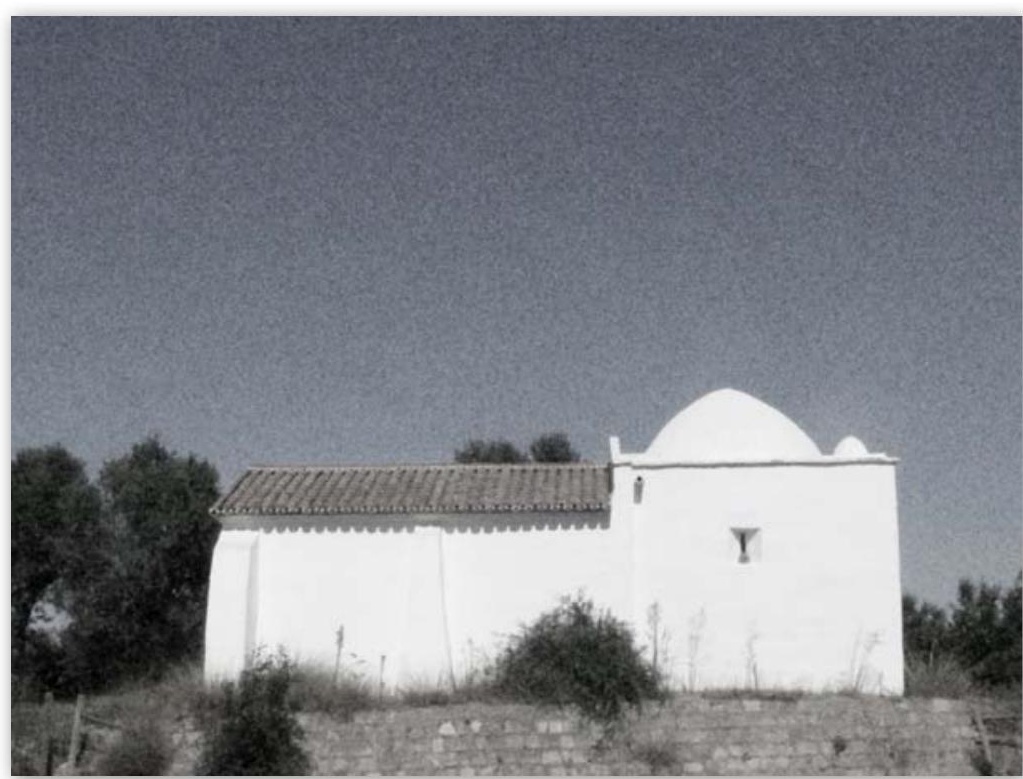

São Vicente, Ferreira do Alentejo, Portugal. 
All the other cubas analysed have undefined measurements that do not comply with the parameters of Roman feet or the Portuguese Andalusian cubit or the Late Gothic cubit.

Nevertheless, other types of data (such as the one concerning building materials and location sites) can also form a valuable instrument in helping with the dating of these structures. Although this data has not yet been gathered, two papers - one by António Rei titled 'O Castelo de Valongo. Estudos métrico-construtivo e histórico-espacial' ('The Valongo Castle: metric-constructive and historico-spatial studies') published in 2000, and the other written by Sergei Chmelnizkij from 1990, entitled 'The Mausoleum of Muhammad Bosharo' - can help guide this investigation further in this respect, since they present two studies similar to the one I have been developing. The first study mentioned has dated the different construction phases of the Valongo Castle through a metric-constructive analysis of the building and through a study of the spelling and semantics of inscriptions found inside the castle. The second study uses a different method to establish the date of construction; Chmelnizkij has conducted a thorough analysis of the metric data and the structural characteristics of the building and reached his conclusion by means of an examination of the composition of the bricks, establishing evidence of the identity of their manufacturer, which then led to the precise date of construction.

\section{Conclusions}

After analysing the thirty-two cubas from the kûra of Beja that I had selected as my objects of study for this article - and even though definite answers to all the questions under debate are not yet possible - I am able to put forward some preliminary conclusions.

Firstly, all the identified cubas are located in spectacular rural settings. The proximity to administrative borders or other architectural sites is not a factor of major importance but apparently an afterthought, since the focus seems to be placed on the inspiring natural surroundings.

Secondly, it is becoming clear that human settlements, bodies of water, rocks, trees, trails, natural springs and high-altitude locations compose the main structure of the theoretical nature of the cubas since they not only define the features that influenced the decision over the choice of building sites, but also denote that the buildings are integrated into the popular religious imagination of those people. Thus, I may claim that the landscape has a very important sociological function since it is a representation of the sacred and of the relation between men and God.

Thirdly, after a thorough analysis of the architectural data collected during the course of this investigation, another conclusion can be drawn. The cubas are a specific type of architectural building project that was carried out over time, adapting to the local culture and eventually blending in with the culture of Alentejo, thus changing that popular culture and becoming a part of that region's heritage.

\begin{tabular}{|c|c|c|c|c|}
\hline Identification & Measurement $(\mathrm{cm})$ & pes & PAC & PLGC \\
\hline Santa Luzia, Alvito & $612.9 \times 610$ & $20.7 \times 20.6$ & $11 \times 11$ & $9.3 \times 9.2$ \\
\hline São Vicente, Ferreira do Alentejo & $502.7 \times 552.4$ & $17.0 \times 18.7$ & $9 \times 10$ & $7.6 \times 8.3$ \\
\hline São Sixto. Cuba & $552.4 \times 502.1$ & $18.7 \times 17$ & $10 \times 10$ & $7.6 \times 8.4$ \\
\hline São Sebastião, Monsaraz & $446.1 \times 445.1$ & $15 \times 15.1$ & $8 \times 8$ & $6.7 \times 6.7$ \\
\hline São João Bap., Monsaraz & $545.8 \times 614.4$ & $18.5 \times 20.8$ & $9.8 \times 11$ & $8.3 \times 9.3$ \\
\hline $\begin{array}{l}\text { Nossa Senhora da Natividade, Ferreira do } \\
\text { Alentejo }\end{array}$ & $529 \times 545.2$ & $17.9 \times 18.4$ & $9.5 \times 9.8$ & $8 \times 8.26$ \\
\hline São Bento, Monsaraz & $488.7 \times 513,6$ & $16.5 \times 17,3$ & $8.8 \times 9.3$ & $7.4 \times 7.8$ \\
\hline São Brás, Serpa & $427.4 \times 425.2$ & $14.5 \times 14.4$ & $7.7 \times 7.7$ & $6.5 \times 6.4$ \\
\hline São Pedro, Alvito & $378.6 \times 398.6$ & $12.8 \times 13.5$ & $6.8 \times 7.2$ & $5.7 \times 6.0$ \\
\hline São Pedro, Villa Nova da Baronia & $379.6 \times 405.5$ & $12.8 \times 13.7$ & $6.8 \times 7.3$ & $5.7 \times 6.1$ \\
\hline
\end{tabular}

Table 4. Metric data of ten cubas from the kûra of Beja. Pes $=$ Roman feet $(1$ pes $=29.57 \mathrm{~cm}) ;$ PAC $=$ Portuguese Andalusian cubit $(1 \mathrm{PAC}=55.5 \mathrm{~cm})$; and PLGC $=$ Portuguese Late Gothic cubit $(1 \mathrm{plgc}=66 \mathrm{~cm})$. The Muslim constructions were often made according to the metric unit known as Portuguese Andalusian cubit. 
To conclude, I would like to present a final note: the study of Islamic architecture is essential to a portrayal of the history and cultural identity of the Iberian Peninsula. What was Hispanic culture and its landscape like before Tariq Ibn Ziyad conquered Iberia, on 1 April 711 ? Is it possible to imagine the Iberian Peninsula without the vital role of Andalusian culture and wealth? Indeed the contribution given by Muslim rulers to Iberian culture is priceless.

Despite the existence of more than three hundred cubas in the south of Portugal, there is little known about these buildings, which represent the most expressive presence of Andalusian culture in Iberian Peninsula. The cubas have been neglected for far too long. It is time to pay attention to these buildings and to give them the respect we owe them as symbols of Iberian-Islamic culture. If we can raise awareness in both the academic community and amongst the political decision-makers about the existence of these buildings and their importance for the understanding of Iberian-Islamic culture, hopefully this investigation can trigger political action that will lead to the development of policies which will ensure the preservation of this important part of our architectural and cultural heritage, as well as bringing back people to visit these sites, now derelict and abandoned, and once again we may see their whitewashed domes reigning over the hills.

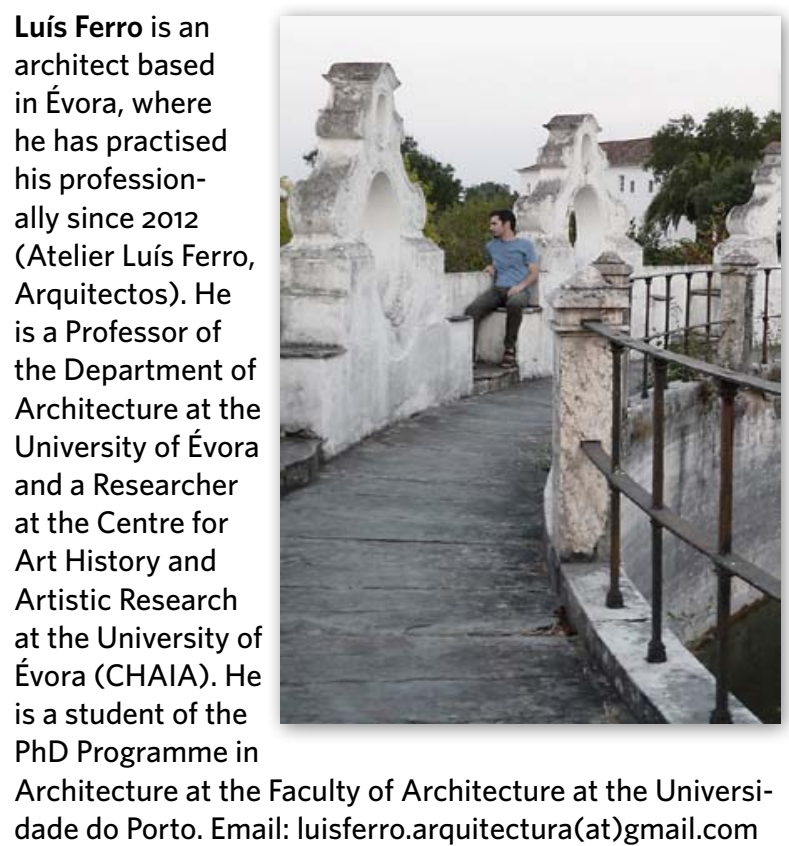

\section{References}

Boiça, Joaquim, 1998. Imaginária de Mértola. Tempos, espaços, representações (Mértola, Campo Arqueológico de Mértola)

Borges, Artur Goulart de Mello, 1985. 'As 'kubbas' alentejanas. Monumentos de origem ou influência Muçulmana no Distrito de Évora' in Actas do Congresso sobre o Alentejo. Semeando novos rumos (Beja, Edição da Associação dos Municípios do Distrito de Beja), pp. 198-204

Carreteiro, Rui Miguel Ramalho, 1997. “Cubas” no Alentejo, academic work on History, Cultural Patrimony (Department of History, University of Évora)

Chmelnizkij, Sergei, 1990. 'The mausoleum of Muhammad Bosharo' in Muqarnas, vol. 7, An Annual on Islamic Art and Architecture, ed. Oleg Grabar (Leiden, E. J. Brill), pp. 23-34

Corriente, Federico, 1986. Diccionário Árabe-Español (Madrid, Intergovernmental Higher Academic Council)

Creswell, K. A. C., 1958. A Short Account of Early Muslim Architecture (Aldershot, Penguin Books Ltd.)

Duby, George, 1992. A história continua (Porto, Edições Asa)

Espírito Santo, Moisés, 1990. A religião popular portuguesa (Lisboa, Assírio \& Alvim)

Gabrieli, Francesco, 1965. Os Árabes (Lisboa, Arcádia)

Gonçalves, José Pires, 1964. 'A cuba de Monsaraz', A Cidade de Évora, Boletim Municipal 47, pp. 198-205

Grassi, Giorgio, 1983. Arquitectura lengua muerta y otros escritos (Barcelona, Ediciones del Serbal)

Macías, Santiago, 2005. Mértola. O último porto do Mediterrâneo (Mértola, Campo Arqueológico de Mértola)

Martos, Rafael Manzano, 1994. La qubba. Aula regia en la España musulmana (Madrid, Real Academia de Bellas Artes de San Fernando)

Rabaça, Armando, 2011. Entre o corpo e a paisagem. Arquitectura e lugar antes do genius loci (Coimbra, Departamento de Arquitectura da Faculdade de Ciências e Tecnologia da Universidade de Coimbra)

Rei, António, 200o. 'O Castelo de Valongo. Estudos métrico-construtivo e histórico-espacial', A Cidade de Évora, Boletim Municipal, II Série, no. 4, pp. 199-218

-2003. 'A fronteira no sudoeste peninsular (1234-1242). Novas revisões da "reconquista" a partir do "alMughrib” de Ibn Saîd de Granada', Arqueologia Medieval 8, pp. 29-41

Varela Gomes, Paulo, 2001. Arquitectura, religião e política em Portugal no século XVII. A planta centralizada (Porto, FAUP publicações)

Yourcenar, Marguerite, 1993. That Mighty Sculptor, Time (New York, Noonday Press) 